Research article

Open Access

\title{
Nongenomic oestrogen signalling in oestrogen receptor negative breast cancer cells: a role for the angiotensin II receptor AT1
}

\author{
Kheng Tian Lim ${ }^{1}$, Niamh Cosgrave ${ }^{1,2}$, Arnold David Hill ${ }^{1,2}$ and Leonie S Young ${ }^{1,2}$
}

\author{
${ }^{1}$ School of Medicine and Medical Science, St. Vincent's University Hospital, Elm Park, Dublin, Ireland \\ ${ }^{2}$ School of Medicine and Medical Science, UCD Conway Institute of Biomolecular and Biomedical Research, UCD Conway Institute, University \\ College Dublin, Dublin, Ireland \\ Corresponding author: Leonie S Young, lyoung@rcsi.ie
}

Received: 13 Jan 2006 Revisions requested: 27 Mar 2006 Revisions received: 24 May 2006 Accepted: 31 May 2006 Published: 28 Jun 2006

Breast Cancer Research 2006, 8:R33 (doi:10.1186/bcr1509)

This article is online at: http://breast-cancer-research.com/content/8/3/R33

(c) 2006 Lim et al.; licensee BioMed Central Ltd.

This is an open access article distributed under the terms of the Creative Commons Attribution License (http://creativecommons.org/licenses/by/2.0), which permits unrestricted use, distribution, and reproduction in any medium, provided the original work is properly cited.

\begin{abstract}
Introduction Oestrogens can mediate some of their cell survival properties through a nongenomic mechanism that involves the mitogen-activated protein kinase (MAPK) pathway. The mechanism of this rapid signalling and its dependence on a membrane bound oestrogen receptor (ER), however, remains controversial. The role of G-protein-coupled receptor and epidermal growth factor (EGF) receptor in an ER-independent signalling pathway modulated by oestrogen was investigated.
\end{abstract}

Methods ER-positive and ER-negative breast cancer cell lines (MCF-7 and SKBR3) and primary breast cancer cell cultures were used in this study. Cell proliferation was assessed using standard MTT assays. Protein and cAMP levels were detected by Western blotting and ELISA, respectively. Antigen localization was performed by immunocytochemistry, immunohistochemistry and immunofluorescence. Protein knockdown was achieved using small interfering RNA technologies.
Results EGF and oestrogen, alone and in combination, induced cell proliferation and phosphorylation of MAPK proteins Raf and ERK (extracellular signal regulated kinase) $1 / 2$ in both ERnegative SKBR3 and ER-positive MCF-7 human breast cancer cell lines. Increased Raf phosphorylation was also observed in primary human breast cultures derived from ER-positive and ERnegative breast tumours. Oestrogen induced an increase in intracellular cAMP in ER-negative SKBR3 human breast cancer cells. Oestrogen-mediated cell growth and phosphorylation of MAPK was modified by the EGF receptor antagonist AG1478, the G-protein antagonist pertussis toxin, and the angiotensin II receptor antagonist saralasin. Knockdown of angiotensin II type 1 receptor (AT1) protein expression with small interfering RNA attenuated oestrogen-induced Raf phosphorylation in ERnegative cells. AT1 receptor was found to be expressed in the cell membrane of breast tumour epithelial cells.

Conclusion These findings provide evidence that, in breast cancer cells, oestrogen can signal through AT1 to activate early cell survival mechanisms in an ER-independent manner.

\section{Introduction}

Oestrogens induce diverse physiological effects that allow normal development and growth of female reproductive tissues, and regulation of bone integrity, cardiovascular function and the central nervous system. Aberrant expression of oestrogen can induce pathophysiological effects that give rise to the growth of tumours, in particular those of the breast. Classically, the mechanism of action of oestrogen was singularly attributed to the binding of nuclear oestrogen receptor (ER) and subsequently activation of target genes over the course of several hours. More recently, it has become clear that oestro- gen may rapidly act on cells in seconds to minutes, implicating a nongenomic mechanism of oestrogen signalling.

In addition to its ability to promote ER-dependent gene transcription, oestrogen rapidly triggers a variety of second messenger signalling events, including mobilization of intracellular calcium [1-3], production of cAMP [4,5], generation of inositol triphosphate [6], and activation of mitogen-activated protein kinase (MAPK) [7-9], phosphatidylinositol 3-OH kinase and AKT/protein kinase B [10-12]. Nongenomic effects of oestrogen purportedly result from the steroid binding a receptor protein in the cell membrane [13].

AT1 = angiotensin II type 1 receptor; EGF = epidermal growth factor; EGFR = epidermal growth factor receptor; ER = oestrogen receptor; ERK $=$ extracellular signal-regulated kinase; GPCR = G-protein-coupled receptor; MAPK = mitogen-activated protein kinase; siRNA = small interfering RNA. 
Membrane ERs have been shown to exist in discrete caveolar domains in the plasma membrane $[14,15]$. Studies in $\mathrm{CHO}$ cells have identified similarly sized nuclear and membrane ER proteins that result from the expression of a single cDNA [16]. Membrane ER is thought to be G-protein linked, with oestrogen binding resulting in activation of many signal transduction pathways that emanate from $\mathrm{G}$ protein activation (for extensive review, see [17]). It was recently reported that the E-domain of membrane ER is required for activation of the MAPK cascade [15] and that serine at amino acid 522 is necessary for the translocation of ER- $\alpha$ to the plasma membrane [18]. In breast cancer cells plasma ER is thought to exist as functional dimers when bound by a steroid ligand [19], but oestrogen-dependent endothelial nitric oxide synthase activation in ER-transfected COS cells may not require dimerization [20].

Studies using ER-negative cell lines suggest that oestrogen may also function in an ER-independent manner. Studies from several laboratories have demonstrated that, in ER-negative cells, oestrogen can signal through the G-protein-coupled receptor (GPCR) GPR30 to transactivate epidermal growth factor receptor (EGFR) and activate the MAPK cascade $[21,22]$. This oestrogen transactivation of EGFR has been shown to be via the release of surface-associated heparinbinding epidermal growth factor [23]. It has been demonstrated that this GPR30-dependent oestrogen induction of MAPK is transient and under the control of a cAMP-dependent negative feedback loop.

Data from the above studies suggest that oestrogen can initiate rapid MAPK signalling in an ER-dependent and ER-independent manner. First, oestrogen can bind a membrane ER, similar or identical to the nuclear receptor, and subsequently activate G proteins; secondly, oestrogen can also directly activate GPCR in the membrane in an ER-independent manner, thereby effecting $G$ protein activation.

More than one GPCR may participate in rapid oestrogen signalling, and it is likely that further complexity in oestrogenmediated GPCR signalling may occur as a result of coupling of different $G$ protein heterodimers with the same receptor. Angiotensin II receptor is of particular interest as a candidate, oestrogen-interacting GPCR. Inwang and colleagues [24] demonstrated expression of angiotensin II type 1 (AT1) receptors in both normal and diseased human breast tissues. Other studies showed that activation of AT1 receptor stimulates growth factor pathways such as tyrosine kinase phosphorylation and induces an increase in phospholipase C, leading to activation of downstream proteins such as MAPK [25], Janus kinases and STAT (signal transducers and activators of transcription) proteins [26]. More recently, a study by Greco and colleagues [27] conducted in MCF-7 cells and primary breast cancer cells revealed that AT1 receptor regulates mitogenic signalling pathways by two simultaneous mechanisms, one involving protein kinase $\mathrm{C}$ and the other EGFR transactivation [27].

We conducted the present study to investigate a combined rapid oestrogen and epidermal growth factor (EGF) activation of the MAPK cascade in both ER-positive and ER-negative breast cancer cells. We describe a role for AT1 in mediating this nongenomic oestrogen-signalling pathway.

\section{Materials and methods}

\section{Cell lines and primary cell cultures}

Human breast cancer cell lines MCF-7 (ER-positive) and SKBR3 (ER-negative) were obtained from American Type Culture Collection (Rockville, MD, USA) and cultured in RPMI 1640 medium (Sigma Ltd, Ireland), enriched with 5\% foetal bovine serum (Sigma Ltd) and supplemented with the antibiotics penicillin $(100 \mathrm{ng} / \mathrm{ml})$ and streptomycin $(100 \mathrm{ng} / \mathrm{ml}$; Invitrogen Ltd, UK) and amphotericin B $(2 \mu \mathrm{g} / \mathrm{ml}$; Invitrogen Ltd, Paisley, UK).

Primary cell cultures derived from histologically confirmed ERpositive and ER-negative breast primary tumours were prepared as previously described [28]. In brief, following ethical approval breast tumour specimens were obtained from patients undergoing surgery for removal of a histologically confirmed breast tumour. Primary tumour epithelial cells were extracted in Hanks' balanced salt solution without calcium or magnesium (Gibco, Paisley, Scotland) supplemented with 1 $\mu \mathrm{mol} / \mathrm{I}$ EDTA and $1 \mu \mathrm{mol} / \mathrm{I}$ DTT for 40 minutes. Cells were cultured in RPMl containing $5 \mu \mathrm{g} / \mathrm{ml}$ insulin, $10 \mu \mathrm{g} / \mathrm{ml}$ transferrin, $30 \mathrm{nmol} / \mathrm{l}$ sodium selinate, $10 \mathrm{nmol} / \mathrm{l}$ hydrocortisone, $10 \mathrm{nmol} /$ I oestradiol, $10 \mathrm{mmol} / \mathrm{l}$ Hepes, $2 \mathrm{mmol} / /$ glutamine, 10\% foetal calf serum (weight/vol) and 5\% ultroser $\mathrm{G}$ on a growth factor reduced matrigel matrix $\left(60 \mathrm{ng} / \mathrm{cm}^{2}\right.$; BD Biosciences, San Jose, CA). Cell viability and epithelial origin of tumour cells were confirmed as previously described [28].

Human breast cancer cells were incubated in a humidified atmosphere of $5 \%$ carbon dioxide at $37^{\circ} \mathrm{C}$. Experiments were carried out when the cells reached $90 \%$ confluence and following 24 hours incubation in serum-free medium without phenol red. Where indicated, cells were preincubated with receptor antagonists 60 minutes before addition of EGF (Sigma) and/or $17 \mu$-oestradiol (10-8 $\mathrm{mol} / \mathrm{l}$; Sigma). EGFRs were inhibited with tyrophostin AG1478 (150 nmol/I), GCPRs with pertussis toxin $(50 \mathrm{ng} / \mathrm{ml})$, and angioteinsin II receptors with saralasin A2275 (1 $\mu \mathrm{mol} / /$; Sigma).

\section{MTT thiozolyl blue proliferation assay}

Cell proliferation was measured using MTT thiazolyl blue assay. Approximately 1,000 cells were seeded in each well of a 96-well plate, cultured, serum starved without phenol red and treated as above. Then, $5 \mathrm{mg} / \mathrm{ml}$ MTT (Sigma) in 1:10 dilution per well was added and incubated for 3-4 hours. The 
(a)

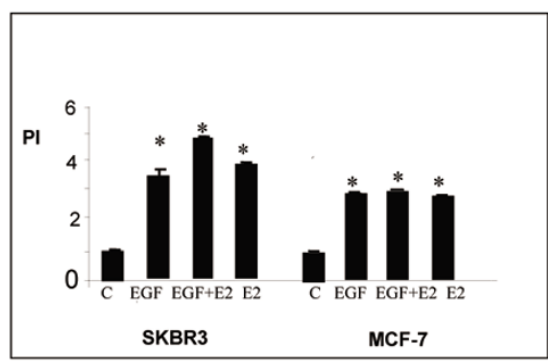

(b)

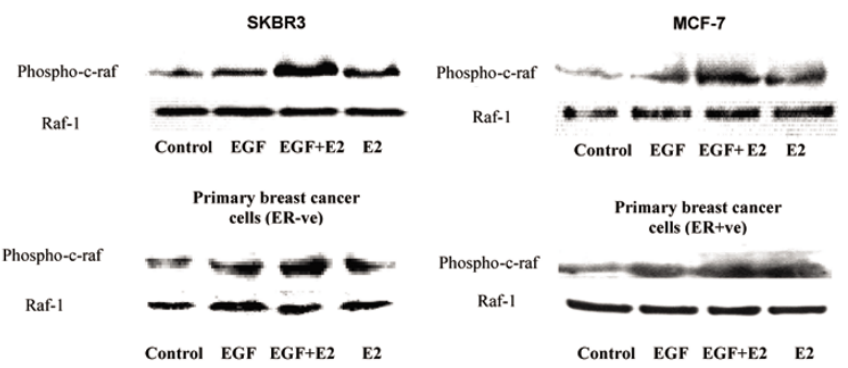

(c)

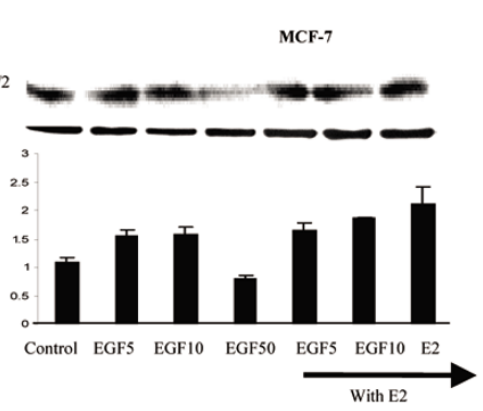

(d)



Effect of 17ß-oestradiol and EGF on cell proliferation and induction of MAPK protein expression in breast cancer cells. (a) Cell proliferation findings. SKBR3 and MCF-7 human breast cancer cells, and ER-negative and ER-positive primary breast cultures derived from patient tumours were treated with EGF $(10 \mathrm{ng} / \mathrm{ml})$ and $17 \beta$-oestradiol $\left(10^{-8} \mathrm{~mol} / \mathrm{l}\right)$ alone and in combination for 24 hours. Cell proliferation assays were carried out using MTT thiozolyl blue. Proliferative index of the control group is standardised to 1 . The results shown are expressed as mean \pm standard error $(n=9)$. Statistical analysis was performed using Mann Whitney $U$ test ( ${ }^{\star} P<0.02$ versus control). (b) Western blot analysis of phospho-Raf and total Raf protein expression. SKBR3 and MCF-7 human breast cancer cells, and ER-negative and ER-positive primary breast cultures derived from patient tumours were treated with EGF $(10 \mathrm{ng} / \mathrm{ml})$ and $17 \beta$-oestradiol $\left(10^{-8} \mathrm{~mol} / \mathrm{l}\right)$ alone and in combination for 10 minutes. (c) Phospo-ERK1/2 and total ERK1/2 protein expression. SKBR3 and MCF-7 human breast cancer cells were treated with 5,10 and $50 \mathrm{ng} / \mathrm{ml}$ EGF and $17 \beta$-oestradiol (10-8 mol/l) alone and in combination for 10 minutes. Results are representative of those obtained in three separate experiments. (d) Immunocytochemical localisation of phospho-ERK in ER-negative SKBR3 cells treated with EGF $(10 \mathrm{ng} / \mathrm{ml})$ and $17 \beta$-oestradiol $\left(10^{-8} \mathrm{~mol} / \mathrm{l}\right)$ alone and in combination for 30 minutes. The slides were counter stained with Mayer's haematoxylin solution and viewed under a light microscope at 200x magnification. Positive cells stained cells stained brown against a blue background. Results are representative of those obtained in three separate experiments. E2, 17 $\beta$-oestradiol; EGF, epidermal growth factor; ER, oestrogen receptor; ERK, extracellular signal regulated kinase; MAPK, mitogen-activated protein kinase; PI, proliferative index. 
Figure 2

(a)
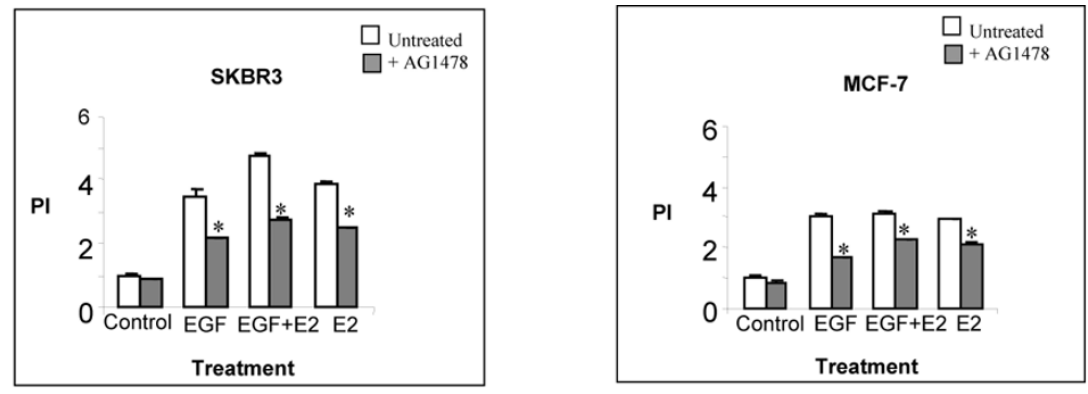

(b)
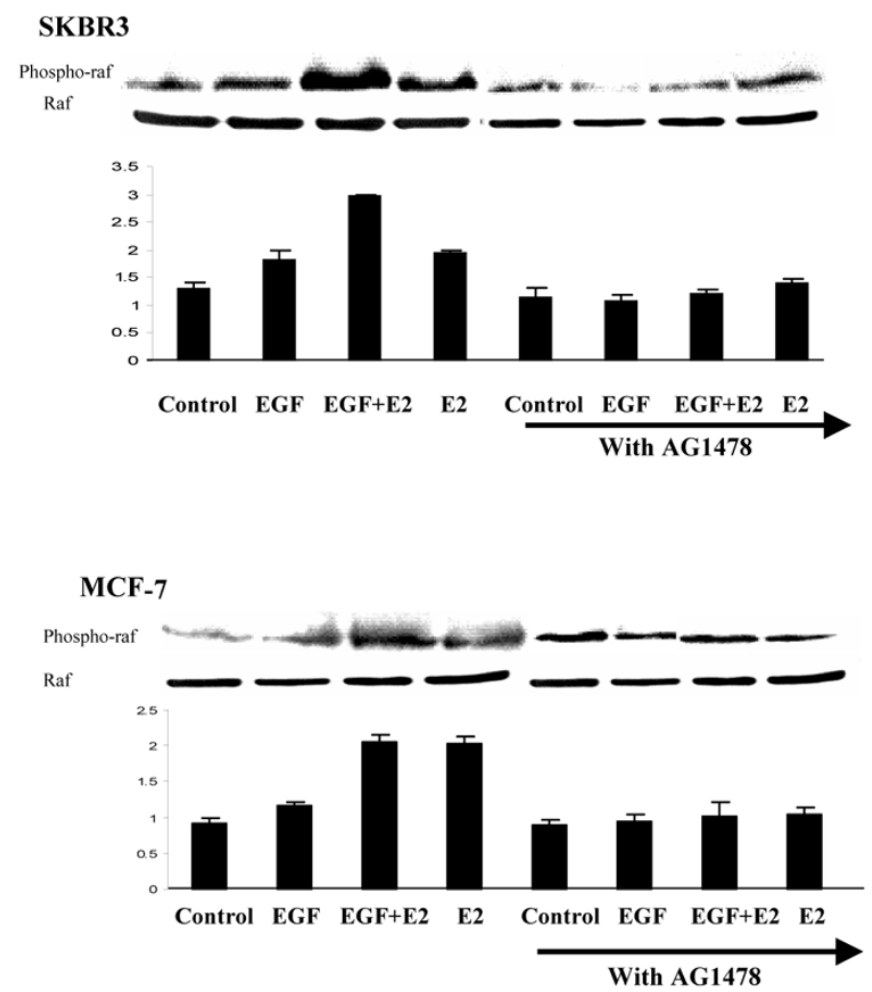

$17 \beta$-estradiol and EGF induced cell proliferation and raf phosphorylation is mediated through EGFR. (a) SKBR3 and MCF-7 breast cancer cells were pretreated with or without the EGFR antagonist AG1478 (150 nmol/l) 1 hour before treatment with EGF $(10 \mathrm{ng} / \mathrm{ml})$ and $17 \beta$-oestradiol $\left(10^{-8}\right.$ $\mathrm{mol} / \mathrm{l})$ alone and in combination for 24 hours. Cell proliferation assays were carried out using MTT thiozolyl blue. Proliferative index of the control group is standardized to 1 . The results shown are expressed as mean \pm standard error $(n=9)$. Statistical analysis was performed using Mann-Whitney $U$ test ${ }^{*} P<0.02$ versus without AG1478). (b) Western blot analysis of phospho-Raf and total Raf in SKBR3 and MCF-7 breast cancer cells pretreated with or without the EGFR antagonist AG1478 (150 nmol/l) for 1 hour before 10 minutes of incubation with EGF (10 ng/ml) and $17 \beta$ oestradiol $\left(10^{-8} \mathrm{~mol} / \mathrm{l}\right)$ alone and in combination. Results are representative of those obtained in three separate experiments. E2, 17 $\beta$-oestradiol; EGFR, epidermal growth factor receptor; PI, proliferative index.

cells were lysed by adding $200 \mu \mathrm{l} /$ well of dimethyl sulfoxide (Sigma Ltd) and read at $570 \mathrm{~nm}$ absorbance wavelength in a microtitre plate spectrophotometer.

\section{Western blot analysis}

Samples containing $50 \mu \mathrm{g}$ protein were electrophoresed on $12 \%$ SDS polyacrylamide gels (Bio-Rad Laboratories Ltd, Hertfordshire, UK) and transferred onto a nitrocellulose mem- brane. The membranes were probed with the phospho-Raf, phospho-ERK (extracellular signal regulated kinase)1/2 (1:1000; Cell Signalling), Raf, ERK1/2 and AT1 $(1 \mu \mathrm{g} / \mathrm{ml}$; Santa Cruz, CA, USA) followed by the corresponding horseradish peroxidase-conjugated mouse or rabbit secondary antibodies (Amersham Biosciences, Buckinghamshire, UK). Chemiluminescence detections were carried out using Lumi- 
(a)

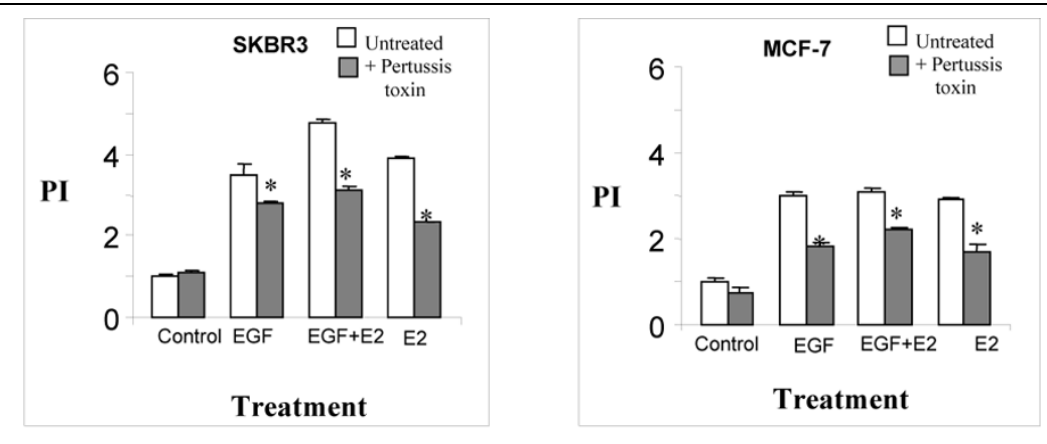

(b)

SKBR3

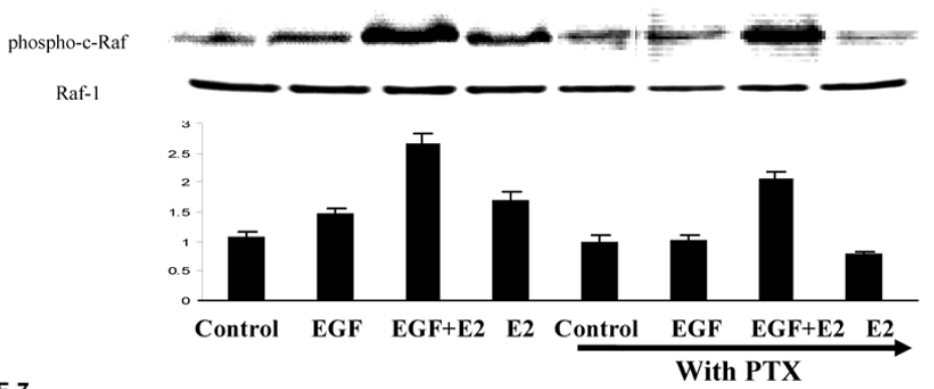

MCF-7

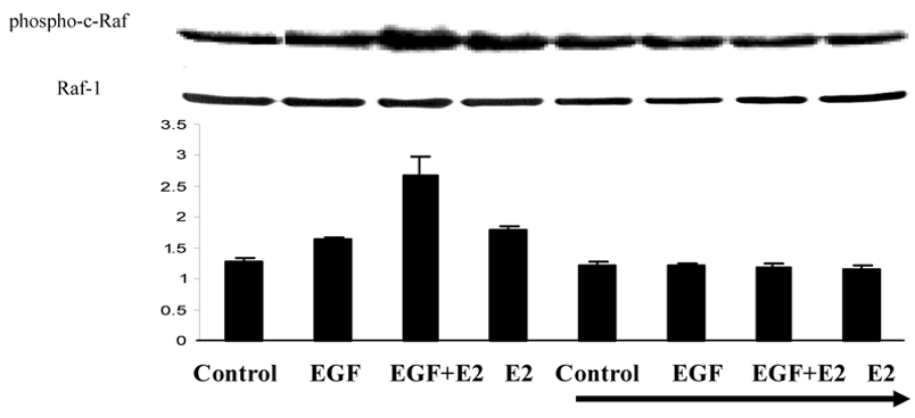

With PTX

(c)

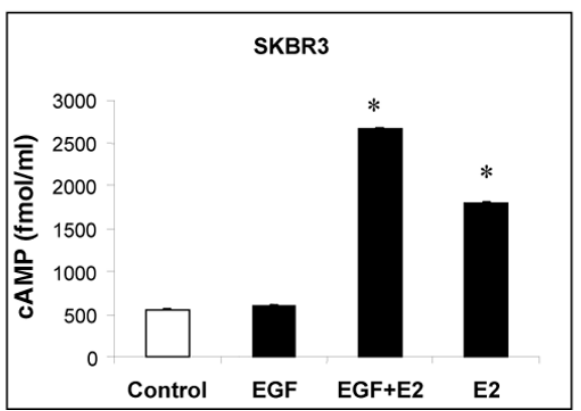

Effect of GPCR antagonism on 17ß-oestradiol and EGF induced cell proliferation, Raf phosphorylation and cAMP production in breast cancer cells. (a) SKBR3 and MCF-7 breast cancer cells pretreated with or without the GPCR antagonist PTX ( $50 \mathrm{ng} / \mathrm{ml}) 1$ hour before 24 hours of incubation EGF $(10 \mathrm{ng} / \mathrm{ml})$ and $17 \beta$-oestradiol $\left(10^{-8} \mathrm{~mol} / \mathrm{l}\right)$ alone and in combination. Cell proliferation assays were carried out using MTT thiozolyl blue. Proliferative index of the control group is standardized to 1. The results shown are expressed as mean \pm standard error $(n=9)$. Statistical analysis was performed using Mann Whitney $U$ test $\left({ }^{\star} P<0.02\right.$ versus without PTX). (b) Western blot analysis of phospho-Raf and total Raf in SKBR3 and MCF7 cells pretreated with or without the GPCR antagonist pertussis toxin $(50 \mathrm{ng} / \mathrm{ml})$ for 1 hour before 10 minutes of incubation with EGF (10 ng/ml) and $17 \beta$-oestradiol $\left(10^{-8} \mathrm{~mol} / \mathrm{l}\right)$ alone and in combination. Results are representative of those obtained in three separate experiments. (c) Intracellular cAMP levels in SKBR3 cells treated with EGF $(10 \mathrm{ng} / \mathrm{ml})$ and $17 \beta$-oestradiol $\left(10^{-8} \mathrm{~mol} / \mathrm{l}\right)$ alone and in combination. Results are expressed as mean \pm standard error $(n=9)$. Statistical analysis was performed using Mann-Whitney $U$ test ( ${ }^{\star} P<0.02$ versus control). E2, 17 $\beta$-oestradiol; EGFR, epidermal growth factor receptor; GPCR, G-protein-coupled receptor; PI, proliferative index. 
nol (Santa Cruz) or enhanced chemiluminescence with SuperSignal (Pierce, Rockford, IL, USA).

\section{CAMP ELISAs}

Concentrations of cAMP were measured using cAMP enzyme immunoassay in accordance with the manufacturer's protocol (Sigma-Aldrich Ireland Ltd, Dublin, Ireland). The assays were performed in a 96-well plate coated with anti-rabbit IgG antibody. The coloured end products, produced by addition of substrate to the wells, were read at $405 \mathrm{~nm}$ absorbance wavelength on a multiwell plate reader. The intensity of the colour was inversely proportional to the concentration of CAMP present in the well.

\section{Immunodetection/microscopy}

Immunodetection was carried out on fixed SKBR3 breast cancer cells and primary breast cancer tissue. Immunocytochemistry and immunohistochemistry were used to detect phosphoERK $1 / 2$ and AT1 on fixed cells and on paraffin-embedded tissue, respectively. SKBR3 cells were cultured on 8-well chamber slides (Lab Tek, Campbell, CA, USA) and subsequently fixed and permeabilized. For tissue, $5 \mu \mathrm{m}$ sections were cut from paraffin-embedded breast tumour blocks and mounted on slides. Sections were dewaxed and rehydrated. Antigen retrieval was performed by immersing section in $0.6 \mathrm{~mol} / \mathrm{l}$ citrate buffer and microwaving on high for 7 minutes. Endogenous peroxidase activity was blocked in fixed cells and tumour sections with 3\% hydrogen peroxide for 20 minutes. Antigens were detected using the Vectastain Elite kit (Vectra Labs, Burlingame, CA, USA) in accordance with the manufacturer's instructions. Briefly, cells and sections were blocked in serum for 90 minutes. Cells and sections were incubated with primary antibodies, mouse anti-human phospho-ERK $1 / 2$ [1:400]; New England Biolabs, Ipswitch, MA, USA) or rabbit anti-human AT1 receptor ( $2 \mu \mathrm{g} / \mathrm{ml}$; Santa Cruz) for 60 minutes at room temperature. Subsequently, sections were incubated in the corresponding biotin-labelled secondary antibody ( 1 in 2000) for 30 minutes, followed by peroxidase-labelled avidin biotin complex. Sections were developed in 3,3-diaminobenzidine tetrahydrochloride and counterstained with haematoxylin. Negative controls were performed using matched IgG controls (Dako, Glostrup, Denmark). Sections were examined under a light microscope.

Immunofluorescence detection of AT1 was performed on SKBR3 cells and primary breast cancer tissue. Cells and tissue were prepared as described above. Breast cancer cells and sections were blocked in 1.5\% normal serum and then incubated with $20 \mu \mathrm{g} / \mathrm{ml}$ rabbit anti-human AT1 in 10\% human serum for 90 minutes. Cells and sections were subsequently incubated with Alexa Fluor 594-conjugated secondary antibody (Molecular Probes, Paisley, UK) for 60 minutes and were counterstained with DAPI (Sigma-Aldrich). Confocal microscopy was performed using a confocal microscope (model MRC 1024; Bio-Rad Laboratories, Hertfordshire, UK) and images were captured using Laser Capture software (Zeiss LSM 510 UV META system, Carl Zeiss Ltd., Hertfordshire, UK).

\section{Small interfering RNA transfection}

Small interfering RNAs (siRNAs) predesigned by Ambion (Austin, TX, USA) were used. The siRNA sequences targeting AT1 (AT1 \#1 [AGTR1 siRNA ID:1988], 5'-GGCCCUAAAGAAGGCUUAUtt-3' [NM_000685]; AT1 \#2 [AGTR1 siRNA ID:2083], 5'-GGCUUAUGAAAUUCAGAAGtt-3' [NM_000685]) were assessed for their ability to downregulate AT1 protein expression. Silencer Negative Control \#1 (scrambled) siRNA or Silencer ${ }^{\circledR}$ GAPDH siRNA (Human; Ambion) were used in accordance with the manufacturer's instructions as control siRNA. SKBR3 cells were transfected using a Nucleofector (Amaxa Biosystems, Cologne, Germany). Cells were transfected with $1.5 \mu \mathrm{g}$ siRNA in Nucleofector solution $\mathrm{V}$ using programme A-23. Immediately following tranfection RPMI was added to the SKBR3 cells, which were then plated in 6-well tissue culture plates overnight. Cells were collected the following day and analyzed for protein expression by Western blotting.

\section{Statistical analysis}

The strengths of associations between the various parameters measured during this study were tested using nonparametric tests, which do not assume that data are normally distributed. Mann-Whitney $U$ test was used to compare two independent groups of sampled data, analyzed by Statview ${ }^{\circledR}$ statistical program (SAS, Cary, NC, USA). Two-sided $P$ values below 0.05 were considered statistically significant. Data are expressed as mean \pm standard error of the mean.

\section{Results \\ $17 \beta$-Oestradiol and EGF alone and in combination induced breast cancer cell proliferation and rapid activation of the MAPK pathway}

Both 17 $\beta$-oestradiol and EGF induced cell proliferation in ERnegative SKBR3 cells and ER-positive MCF-7 cells (Figure 1a). In SKBR3 cells, combined treatment with 17 $\beta$-oestradiol and EGF induced a further increase in cell proliferation compared with either treatment alone. To examine the effect of $17 \beta$-oestradiol and growth factor treatment on MAPK activation, we examined their ability to induce phosphorylation of Raf and ERK1/2. In ER-positive and ER-negative breast cancer cell lines and in primary cell cultures derived from patient tumours, both $17 \beta$-oestradiol and EGF increased expression of phospho-Raf and phospho-ERK1/2 (Figure 1b, c). Combined treatment with steroid and growth factors resulted in a further increase in phosphorylation of the MAPK proteins. The ability of $17 \beta$-oestradiol and EGF to mobilize ERK1/2 was also examined. Increased nuclear localization of phospho-ERK1/2 was observed in the presence of EGF and in particular in the presence of $17 \beta$-oestradiol and $17 \beta$-oestradiol in combination with EGF (Figure 1d). 
(a)
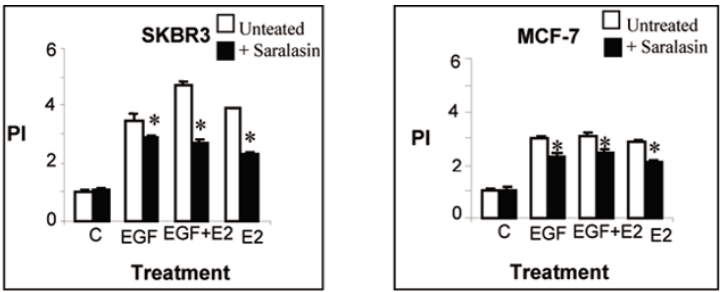

(b)

SKBR3



(c)

With saralasin

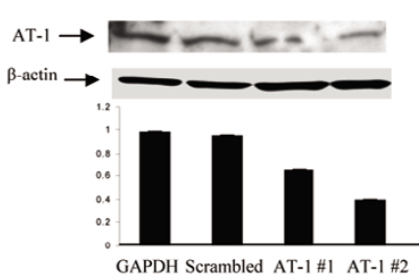

siRNA

(d)

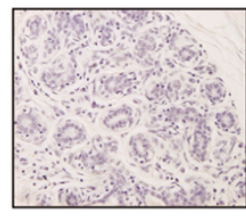

Negative control IgC

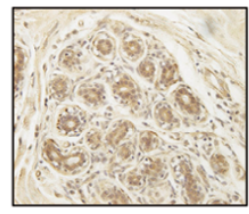

AT-1 40X

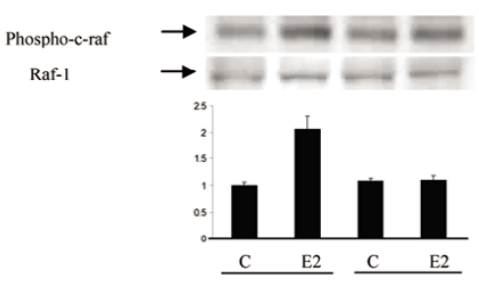

Scrambled siRNA AT-1 siRNA

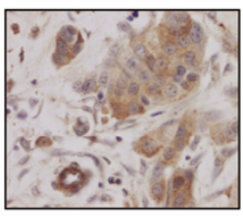

AT-1 200X

(e)

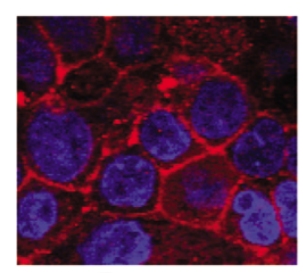

Breast tumour



SKBR3

The role of the AT1 receptor in 17 $\beta$-oestradiol and EGF-mediated cell proliferation and Raf phosphorylation in breast cancer cells. (a) SKBR3 and MCF-7 breast cancer cells pretreated with or without angiotensin II receptor antagonist saralasin $\left(10^{-6} \mathrm{~mol} / \mathrm{l}\right) 1$ hour before 24 hours of incubation with EGF $(10 \mathrm{ng} / \mathrm{ml})$ and $17 \beta$-oestradiol $\left(10^{-8} \mathrm{~mol} / \mathrm{l}\right)$ alone and in combination. Cell proliferation assays were carried out using MTT thiozolyl blue. Proliferative index of the control group is standardized to 1 . The results shown are expressed as mean \pm standard error $(n=9)$. Statistical analysis was performed using Mann-Whitney $U$ test $\left({ }^{\star} P<0.02\right.$ versus without saralasin). (b) Western blot analysis of phospho-Raf and total Raf in SKBR3 cells pretreated with or without the AT1 antagonist saralasin $\left(10^{-6} \mathrm{~mol} / \mathrm{l}\right)$ for 1 hour before 10 minutes of incubation with EGF (10 $\left.\mathrm{ng} / \mathrm{ml}\right)$ and $17 \beta-$ oestradiol $\left(10^{-8} \mathrm{~mol} / \mathrm{l}\right)$ alone and in combination. Results are representative of those obtained in three separate experiments. (c) Western bolt analysis of AT1 and phospho-Raf in SKRB3 cells transiently transfected with GAPDH siRNA, scrambled siRNA, or AT1 (\#1 or \#2) siRNA before treatment with $17 \beta$-oestradiol $\left(10^{-8} \mathrm{~mol} / \mathrm{l}\right)$ for 10 minutes. Results are representative of those obtained in three separate experiments. Optical density readings of control values were normalized to 1 and experimental groups were expressed as a ratio. Values are expressed as mean \pm standard error $(n=3)$. (d) Immunohistochemistry was carried out for AT1 receptor on primary human breast cancer tissue $(7 \mu \mathrm{m})$. Negative control was matched $\mathrm{lgG}$. The slides were counterstained with Mayer's haematoxylin solution and were viewed under a light microscope at $40 \times$ and $200 \times$ magnifications. Positive cells stained cells stained brown against a blue background. (e) Immunofluorescence studies of AT1 receptor in human primary tumour breast cancer tissue $(7 \mu \mathrm{m})$ and SKBR3 breast cancer cells. Slides were viewed under a confocal microscope at 630x. AT1, angiotensin II type 1; E2, 17ß-oestradiol; EGFR, epidermal growth factor receptor; siRNA, small interfering RNA. 


\section{Rapid estrogen signalling is dependent on tyrosine kinase receptors}

It has been reported that oestrogen transactivates the EGFR to initiate the MAPK cascade. To examine the role of tyrosine kinase receptor EGFR in mediating $17 \beta$-oestradiol-induced cell proliferation and MAPK activation in ER-positive and ERnegative breast cancer cells, we inhibited EGFR with the specific inhibitor AG1478. 17ß-Oestradiol and EGF induced cell proliferation was attenuated in the presence of AG1478 (Figure 2a). The EGFR antagonist also diminished steroid and growth factor induced Raf phosphorylation in both SKBR3 and MCF-7 breast cancer cell lines (Figure 2b).

\section{Oestrogen can signal through G proteins in ER-positive and ER-negative breast cancer cell lines}

It has been suggested that oestrogens can activate either membrane-bound ER or GPCR to initiate rapid cell signalling events. We examined the role of $\mathrm{G}$ proteins in $17 \beta$-oestradiol and EGF-induced cell phosphorylation and activation of the MAPK pathway, in ER-positive and ER-negative cell lines. The $G$ protein antagonist pertussis toxin inhibited $17 \beta$-oestradiol cell growth and Raf phosphorylation in both ER-positive and ER-negative cell lines (Figure 3a, b). Of interest, treatment with pertussis toxin also abrogated the cell growth and Raf phosphorylation seen in the presence of EGF and EGF in combination with $17 \beta$-oestradiol, in particular in ER-positive MCF-7 breast cancer cells (Figure $3 a, b)$. We assessed the ability of $17 \beta$-oestradiol and EGF to induce the classic GPCR second messenger cAMP. In SKBR3 cells, levels of CAMP were increased in the presence of $17 \beta$-oestradiol and in the presence of $17 \beta$-oestradiol in combination with EGF (Figure 3c).

\section{Oestrogens can signal through the angiotensin II receptor AT1 in human breast cancer cells}

A role for the GPCR AT1 was assessed in ER-positive and ERnegative breast cancer cells. Treatment with the AT1 receptor antagonist saralasin resulted in attenuation of $17 \beta$-oestradiol and EGF induced cell proliferation in the ER-negative SKBR3 cells and, to a lesser extent, in the ER-positive MCF-7 cells (Figure 4a). In the SKBR3 cells saralasin inhibited 17 $\beta$-oestradiol induced phosphorylation of Raf (Figure 4b). To investigate further the role of the AT1 receptor, we knocked down AT1 using siRNA technology. Two predesigned siRNA sequences targeting AT1 (AT1 \#1 and AT1 \#2) were assessed for their ability to knock down AT1 protein expression, compared with siRNA sequences targeting GAPDH and scrambled siRNA. AT1 \#2 siRNA was found to be more effective at downregulating AT1 protein expression and was therefore used in subsequent experiments (Figure $4 \mathrm{c}$ ). The ability of $17 \beta$-oestradiol to induce Raf phosphorylation in SKBR3 cells was attenuated in cells transfected with AT1 \#2 siRNA compared with scrambled control (Figure 4c).

In paraffin-embedded breast cancer tissue AT1 protein was found to be expressed predominantly in breast tumour epithe- lial cells, with little staining detected in the surrounding stromal cells (Figure 4d). In order to determine cellular localization of AT1 we performed confocal microscopy. AT1 was found to be expressed predominantly at the cellular membrane in tumour epithelial cells of breast cancer tissue and in the SKBR3 breast cancer cell line (Figure 4e).

\section{Discussion}

The ability of oestrogen to transactivate EGFRs rapidly in a Gcoupled protein dependent manner has now been established. The mechanism of this 'nongenomic' oestrogen signalling and its dependence on a membrane-bound ER, however, remains controversial. Studies have shown that membrane ER is similar if not identical to nuclear ER [16], which is linked to $G$ proteins, activating several second messenger systems [29]. Investigations using ER-negative cell lines have demonstrated that oestrogen may also function through ER-independent mechanisms. GPCRs, and in particular GPR30, the orphan GPCR, have been implicated in mediating this ERindependent oestrogen signalling $[21,22]$. In this study we examined rapid oestrogen signalling in ER-positive and ERnegative, breast cancer cell lines and primary breast cancer cells derived from patient tumours and investigated a role for the GPCR AT1 in mediating this effect.

Nongenomic actions of oestrogen result in an array of downstream signalling events, which are thought to be largely cell specific. In breast cancer, rapid oestrogen events have been shown to include accumulation of CAMP, ERK $1 / 2$ and c-fos $[22,30]$. In these studies $17 \beta$-oestradiol and EGF induced increased cell proliferation in both ER-positive MCF-7 and ERnegative SKBR3 breast cancer cell lines. We examined the ability of $17 \beta$-oestradiol and EGF alone and in combination to activate the MAPK cascade. In breast cancer cell lines and in primary breast tumour cell cultures, expression of ER was not required for $17 \beta$-oestradiol induced phosphorylation of Raf. Furthermore, in line with other investigators who have described activation of ERK1/2 in ER-negative cells [21], we found that $17 \beta$-oestradiol induced ERK1/2 phosphorylation and translocation from the cytosol to the nucleus in SKBR3 cells. The ability of oestrogens to initiate the MAPK cascade has been linked to $G \beta \gamma$ protein dependent release of surface associated heparin-binding EGF, resulting in transactivation of the EGFR $[21,23]$. Here, requirement of EGFR transactivation for maximal oestrogen-mediated cell proliferation and MAPK activation was established using the receptor EGF inhibitor AG1478.

Both ER-dependent and ER-independent transactivation of EGFR has been shown to signal via $G$ coupled proteins, with several different $G$ protein heterodimers coupling with the same receptor. Membrane ER can co-immunoprecipitate with Gs and Gq proteins in transfected and endogenous ER cell models [16,19], and in ER-negative cells oestrogen-GPR30 dependent activation of MAPK is sensitive to the Gi/o-protein 
inhibitor pertussis toxin [22]. Here, pertussis toxin attenuated $17 \beta$-oestradiol induced cell proliferation and Raf phosphorylation in both ER-positive and ER-negative breast cancer cell lines. Of interest, pertussis toxin also attenuated EGF-induced breast cancer cell proliferation and phospho-Raf expression. These observations are consistent with those of other investigators that have observed pertussis toxin induced reductions in growth factor mediated ERK1/2 activation [31,32]. It has been proposed that these effects may be mediated via pertussis toxin induced disinhibition of CAMP [31]. To assess further the role of $G$ coupled proteins we evaluated the accumulation of the GPCR second messenger cAMP, in response to both $17 \beta$-oestradiol and EGF. As previously reported $17 \beta$-oestradiol induced cAMP levels in ER negative SKBR3 breast cancer cells [23]. Although EGF alone had no effect on cAMP accumulation, EGF synergistically increased oestrogeninduced $\mathrm{CAMP}$, providing further evidence of crosstalk between tyrosine kinase receptors and $G$ proteins.

Mediation of the nongenomic effects of oestrogens are likely to occur in a cell-specific manner, with more than one GPCR participating in rapid oestrogen signalling. In addition to GPR30, the membrane bound sex hormone binding globulin receptor can mediate oestrogen-induced activation of adenylate cyclase via the Gs protein subunit. The angiotensin II receptor AT1 is another attractive oestrogen-signalling GPCR candidate. AT1 is a Gq/i coupled receptor, which can lead to tyrosine kinase phosphorylation, increased phospholipase C $[25,26]$ and Raf-ERK $1 / 2$ activation, which can be partially inhibited by pertussis toxin [33]. Expression of AT1 in normal and diseased breast tissue has previously been reported [24]. In the present study immunohistochemistry performed on primary breast cancer tissue revealed AT1 receptor staining primarily in breast tumour epithelial cells. At a cellular level AT1 was found to be predominantly expressed in the membrane of tumour epithelial cells and ER-negative breast cancer cell lines. Here, we investigated the role of the AT1 in mediating the nongenomic effects of oestrogens in ER-positive and ERnegative breast cancer cells. The angiotensin II receptor competitive inhibitor saralasin attenuated the proliferative effects of $17 \beta$-oestradiol and EGF in SKBR3 and MCF-7 breast cancer cells, in a similar manner to that seen for pertussis toxin. Of interest, the inhibitory effects of saralasin were found to be greater in the ER-negative cells than in ER-positive cells, which is consistent with the proposed cell specific nature of nongenomic estrogen signalling. Furthermore, 17 $\beta$-oestradiol mediated Raf phosphorylation was inhibited in the presence of saralasin in SKBR3 cells. To confirm a role for AT1 in nongenomic oestrogen signalling in ER-negative cells, we knocked down AT1 expression with siRNA. Downregulation of AT1 also attenuated $17 \beta$-oestradiol induction of phospho-Raf in the ERnegative SKBR3 cells.

\section{Conclusion}

The mechanisms by which oestrogen couples to $G$ proteins to mediate its nongenomic effects are likely to be varied and cell context specific. The data presented here indicate that estrogens can activate early cell survival signalling in an ER-independent manner not only in ER-negative cell lines but also in primary breast cultures. We propose that this ER-independent oestrogen signalling is mediated, at least in part, through the GPCR AT1. These data suggest that in a clinical setting aromatase inhibitors may be beneficial in treating ER-negative as well as ER-positive breast tumours. Elucidation of the components of the nongenomic oestrogen signalling cascade will provide important information regarding the role of oestrogens in physiological and pathophysiological conditions.

\section{Competing interests}

The authors declare that they have no competing interests.

\section{Authors' contributions}

$\mathrm{KL}$ performed cell cultures, proliferation assays, Western blot analysis and ELISA studies. NC completed immunofluorescence and knockdown studies. $\mathrm{AH}$, supplied tumour specimens and provided clinical interpretation of data. LY contributed to conception and design of study and interpretation of data. All authors read and approved the final manuscript.

\section{References}

1. Morley P, Whitfield JF, Vanderhyden BC, Tsang BK, Schwartz JL: A new, nongenomics estrogen action: the rapid release of intracellular calcium. Endocrinology 1992, 131:1305-1312.

2. Audy MC, Vacher P, Duly B: $17 \beta$-estradiol stimulates a rapid $\mathrm{Ca}^{2+}$ influx in LNCaP human prostate cancer cells. Eur $\mathrm{J}$ Endocrinol 1996, 135:367-373.

3. Improta-Brears T, Whorton AR, Codazzi F, York JD, Meyer T, McDonnell DP: Estrogen-induced activation of mitogen-activated protein kinase requires mobilization of intracellular calcium. Proc Natl Acad Sci USA 1999, 96:4686-4691.

4. Nakhla AM, Khan MS, Rosner W: Biologically active steroids activate receptor-bound human sex hormone-binding globulin to cause LNCaP cells to accumulate adenosine 3', 5'-monophosphate. J Clin Endocrinol Metab 1990, 71:398-404.

5. Aronica SM, Kraus WL, Katzenellenbogan BS: Estrogen action via the CAMP signalling pathway: stimulation of adenylate cyclase and cAMP-regulated gene transcription. Proc Nat Acad Sci USA 1994, 91:8517-8521.

6. Le Mallay V, Grosse B, Lieberherr M: Phospholipase C beta and membrane action of calcitriol and estradiol. J Biol Chem 1997, 272:11902-11907.

7. Migliaccio A, Di Domenico M, Castoria G, de Falco P, Bontempo $P$, Nola E, Auricchio F: Tyrosine kinase/p21ras/MAP kinase pathway activation by estradiol-receptor complex in MCF-7 cells. EMBO J 1996, 15:1292-1300.

8. Endoh H, Sasaki H, Maruyama K, Takeyama K, Waga I, Shimizu T, Kato $\mathrm{S}$, Kawashima $\mathrm{H}$ : Rapid activation of MAP kinase by estrogen in the bone cell line. Biochem Biophys Res Commun 1997, 235:99-102.

9. Watters JJ, Campbell JS, Cunningham MJ, Krebs EG, Dorsa EM: Rapid membrane effects of steroids in neuroblastoma cells: effects of estrogen on mitogen-activated protein kinase signalling cascade and c-fos immediate early gene transcription. Endocrinology 1997, 138:4030-4033.

10. Chambliss KL, Yuhanna IS, Mineo C, Liu P, German Z, Sherman TS, Mendelsohn ME, Anderson RG, Shaul PW: Estrogen receptor alpha and endothelial nitric oxide synthase are organized 
into a functional signalling module in caveolae. Circ Res 2000, 87:E44-E52.

11. Haynes MP, Sinha D, Russell KS, Collinge M, Fulton D, MoralesRuiz M, Sessa WC, Bender JR: Membrane estrogen receptor engagement activates endothelial nitric oxide synthase via the PI3-kinase-AKT pathway in human endothelial cells. Circ Res 2000, 87:677-682.

12. Martin MB, Franke TF, Stoica GE, Chambon $P$, Katzenellenbogen BS, Stoica BS, McLemore MS, Olivo SE, Stoica A: A role for AKT in mediating the estrogenic functions of epidermal growth factor and insulin-like growth factor I. Endocrinology 2000, 141:4503-4511.

13. Levin ER: Cellular functions of the plasma membrane estrogen receptor. Trends Endocrinol Metab 1999, 10:374-377.

14. Kim HP, Lee JY, Jeong JK, Bae SW, Lee HK, Jo I: Non-genomic stimulation of nitric oxide release by estrogen is mediated by ER-alpha localised in caveolae. Biochem Biophys Res Commun 1999, 263:257-263.

15. Razandi M, Oh P, Pedram A, Schnitzer J, Levin ER: Estrogen receptors associated with and regulate the production of caveolin: Implications for signalling and cellular actions. Mol Endocrino/ 2002, 16:100-115.

16. Razandi M, Pedram A, Greene GL, Levin ER: Cell membrane and nuclear estrogen receptors (ERs) originate from a single transcript: studies of ER-alpha and ER-beta expressed in Chinese hamster ovary cells. Mol Endocrinol 1999, 13:307-319.

17. Levin ER: Integration of the extranuclear and nuclear actions of estrogen. Mol Endocrinol 2005, 19:1951-1959.

18. Evinger AJ, Levin ER: Requirements for ER-alpha membrane localisation and function. Steroids 2005, 70:361-368.

19. Razandi M, Pedram A, Merchenthaler I, Greene GL, Levin ER: Plasma membrane estrogen receptors exist and function as dimmers. Mol Endocrinol 2004, 18:2854-2865.

20. Chambliss KL, Simon L, Yuhanna IS, Mineo C, Shaul PW: Dissecting the basis of nongenomic activation of eNOS by estradiol: Role of ER-alpha domains with known nuclear functions. Mol Endocrinol 2005, 19:277-289.

21. Filardo EJ, Quinn JA, Bland KI, Frackelton AR Jr: Estrogen induced activation of Erk-1 and Erk-2 requires the G-proteincoupled receptor homolog, GPR30, and occurs via transactivation of the epidermal growth factor receptor through release of HB-EGF. Mol Endocrinol 2000, 14:1649-1660.

22. Maggiolini M, Vivaeaqua A, Fasanella G, Recchia AG, Sisci D, Pezzi V, Mantanaro D, Musti AM, Picard D, Ando S: The G proteincoupled receptor GPR30 mediates c-Fos up-regulation by both 17-beta-estradiol and phytoestrogens in breast cancer cells. J Biol Chem 2004, 279:27008-27016.

23. Filardo EJ, Quinn JA, Frackelton AR Jr, Bland KI: Estrogen action via the G protein-coupled receptor, GPR30: stimulation of adenylyl cyclase and CAMP-mediated attenuation of the epidermal growth factor receptor-to-MAPK signalling axis. Mol Endocrinol 2002, 16:70-84.

24. Inwang ER, Puddefoot JR, Brown CL, Goode AW, Marsigliante S, Ho MM, Payne JG, Vinson GP: Angiotensin II type 1 receptor expression in human breast tissues. $\mathrm{Br} J$ Cancer 1997, 75:1279-1283.

25. Schieffer B, Paxton WG, Marrero MB, Bernstein KE: Importance of tyrosine phosphorylation in angiotensin II type 1 receptor signalling. Hypertension 1996, 27:476-480.

26. Marrero MB, Schieffer B, Paxton WG, Heerdt L, Berk BC, Delafontaine $\mathrm{P}$, Bernstein KE: Direct stimulation of Jak/STAT pathway by the angiotensin II AT1 receptor. Nature 1995, 375:247-250.

27. Greco S, Muscella A, Elia MG, Salvatore P, Storelli C, Mazzotta A, Manca C, Marsigliante S: Angiotensin II activates extracellular signal regulated kinases via protein kinase $C$ and epidermal growth factor receptor in breast cancer cells. J Cell Physiol 2003, 196:370-377.

28. Myers E, Fleming JF, Crotty TB, Kelly G, McDermott EW, O'Higgins NJ, Hill AD, Young LS: Inverse relationship between ERbeta and SRC-1 predicts outcome in endocrine resistant breast cancer. Br J Cancer 2004, 91:1687-1693.

29. Razandi M, Pedram A, Park ST, Levin ER: Proximal events in signalling by plasma membrane estrogen receptors. J Biol Chem 2003, 278:2701-2712.

30. Filardo EJ: Epidermal growth factor receptor (EGFR) transactivation by estrogen via the G-protein-coupled receptor, GPR30: a novel signalling pathway with potential significance for breast cancer. J Steroid Biochem Mol Bio/ 2002, 80:231-238.

31. Piiper A, Gebhardt R, Kronenberger D, Giannini C, Elez R, Zeuzem $S:$ Pertussis toxin inhibits cholecystokinin-and epidermal growth factor induced mitogen activated protein kinase activation by disinhibition of the CAMP signalling pathway and inhibition of c-Raf-1. Mol Pharmacol 2000, 58:608-613.

32. Melien O, Sandnes D, Johansen J, Christoffersen T: Effects of pertussis toxin on extracellular signal regulated kinase activation in hepatocytes by hormones and receptor-independent agents: evidencesuggesting a stimulatory role of Gi proteins at a level distal to receptor coupling. J Cell Physiol 2000, 184:27-36.

33. Smith RD, Baukal AJ, Dent $P$, Catlk J: Raf-1 kinase activation by angiotensisn II in adrenal glomerulosa cells: roles for Gi, phosphalidylinositol 3-kinase and $\mathrm{Ca}^{2+}$ influx. Endocrinology 1999, 140:1385-1391. 